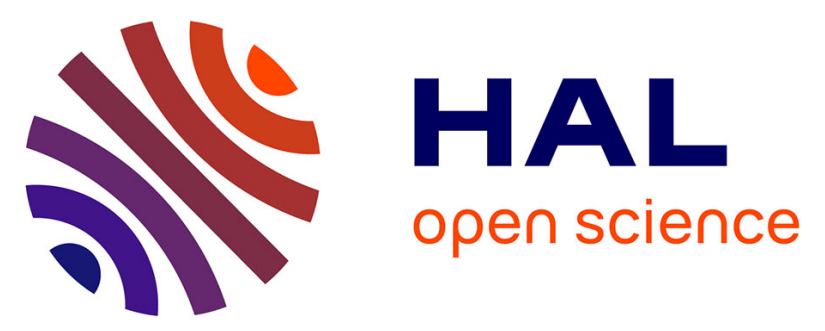

\title{
Performance Assessment of Tank Fluid Purging and Night Cooling as Overheating Prevention Techniques for Photovoltaic-Thermal (PV-T) Solar Water Heating Systems
}

\author{
Pedro Magalhães, João Martins, António Joyce
}

\section{To cite this version:}

Pedro Magalhães, João Martins, António Joyce. Performance Assessment of Tank Fluid Purging and Night Cooling as Overheating Prevention Techniques for Photovoltaic-Thermal (PV-T) Solar Water Heating Systems. 8th Doctoral Conference on Computing, Electrical and Industrial Systems (DoCEIS), May 2017, Costa de Caparica, Portugal. pp.337-347, 10.1007/978-3-319-56077-9_33 . hal-01629594

\section{HAL Id: hal-01629594 \\ https://hal.inria.fr/hal-01629594}

Submitted on 6 Nov 2017

HAL is a multi-disciplinary open access archive for the deposit and dissemination of scientific research documents, whether they are published or not. The documents may come from teaching and research institutions in France or abroad, or from public or private research centers.
L'archive ouverte pluridisciplinaire HAL, est destinée au dépôt et à la diffusion de documents scientifiques de niveau recherche, publiés ou non, émanant des établissements d'enseignement et de recherche français ou étrangers, des laboratoires publics ou privés.

\section{(c)(1)}

Distributed under a Creative Commons Attribution| 4.0 International License 


\title{
Performance Assessment of Tank Fluid Purging and Night Cooling as Overheating Prevention Techniques for Photovoltaic-thermal (PV-T) Solar Water Heating Systems
}

\author{
Pedro M. L. P. Magalhães ${ }^{1,2}$, João F. A. Martins ${ }^{1,2}$ and António L. M. Joyce ${ }^{3}$ \\ ${ }^{1}$ Centre of Technology and Systems, UNINOVA, Quinta da Torre, \\ 2829-516 Monte de Caparica, Portugal \\ ${ }^{2}$ Faculty of Science and Technology, NOVA University of Lisbon, Quinta da Torre, \\ 2829-516 Monte de Caparica, Portugal \\ ${ }^{3}$ National Laboratory of Energy and Geology, Estrada do Paço do Lumiar 22, \\ 1649-038 Lisbon, Portugal \\ Corresponding author: Pedro Magalhães, pmlpm@campus.fct.unl.pt
}

\begin{abstract}
Tank fluid purging and night cooling are two overheating prevention techniques with potential to prevent photovoltaic-thermal collectors from experiencing temperatures capable of undermining their longevity and commercial appeal. Both techniques are readily available, inexpensive but inherently wasteful to use. Dynamic numerical simulations were conducted to determine the primary energy efficiency and the level of protection afforded by these techniques in active residential grid-connected solar domestic hot water systems. Also evaluated was the use of occupancy rate information, possible via so-called "smart systems", to complement the techniques. The results revealed better performances for systems using stagnation control schemes relative to those not using them. Also, night cooling was shown to be unable to prevent overheating reliably while tank fluid purging proved to be more apt but resulted in substantial waste of water annually, which could be reduced by combining it with night cooling, which in turn revealed the highest performances observed.
\end{abstract}

Keywords: photovoltaic; thermal; stagnation; night; cooling; purging

\section{Introduction}

Solar water heating systems such as those for domestic hot water or space heating routinely experience stagnation events, particularly during the Summer months. During this period, ambient temperature and irradiation levels are at their highest and demand tends to be low by design (e.g., space heating) or due to absence periods (e.g., vacations). While standard collectors for low temperature applications $\left(<100^{\circ} \mathrm{C}\right)$ such as flat-plate and evacuated tube collectors are generally designed to withstand their worst case scenario stagnation temperatures $\left(100-300^{\circ} \mathrm{C}\right)$, hybrid photovoltaic-thermal (PV-T) collectors are sensitive to temperatures in excess of $85^{\circ} \mathrm{C}$ - in part due to the 
limited temperature stability of common photovoltaic (PV) array encapsulants, namely ethylene vinyl acetate (EVA) - which can occur during stagnation [1-2]. As a result, PV-T systems require stagnation control methods to prevent overheating in addition to the protections typically required in standard solar heating systems.

Stagnation control methods commonly used in solar heating systems can be categorised as either stagnation handling or overheating prevention [3]. Stagnation handling methods do not prevent stagnation but instead mitigate its harmful consequences such as thermal stress to other components in the collector circuit due to heat carrier evaporation, heat carrier degradation, accelerated corrosion and plugging of pipes [4]. Examples of stagnation handling methods include the drainback, draindown and steamback systems or the use high system pressures in the collector loop [2]. In contrast, overheating prevention methods avoid the onset of temperatures capable of compromising a system's functional integrity by avoiding stagnation or limiting the temperatures reached. Examples include collector shading systems, night cooling of the storage tank, tank fluid purging, active heat dumping, passive venting and defocusing (for tracking systems). Of the two categories, overheating prevention methods are necessary for glazed PV-T systems, whose temperatures can reach around $150^{\circ} \mathrm{C}$ under stagnation, even though some stagnation handling measures can be seen as desirable or complementary $[1,2,5,6]$.

The present endeavour focuses on the performance of two overheating prevention methods, namely tank fluid purging and night cooling of the storage tank, in active residential solar domestic hot water (SDHW) systems using glazed PV-T collectors producing electricity and feeding it to the local utility grid using grid-tie inverters. Both methods have a low initial cost - one of which (night cooling) is a common feature in many commercial controllers - and are designed to lower the storage tank temperature and in doing so indirectly prevent stagnation and high temperatures.

Tank fluid purging consists of disposing of hot tank fluid - generally water - using a single purge valve and replacing it with colder fluid to prevent the tank from being fully charged. In doing so, stagnation due to low temperature differences between the collector and tank or due to the maximum allowed collector temperature being reached can be avoided indirectly. However, the hottest fluid in the tank (i.e., from the top) is wasted and in the case of water predominantly when it is scarce (Summer months) while requiring parasitic energy to power the pump(s) and valve - assuming the latter is not thermostatic. On the other hand, the method is unsuitable for some fluids and the valve is used sparingly during the Winter months which may cause it to fail prematurely unless periodic discharges or careful maintenance is carried out [2].

In contrast, night cooling of the storage tank does so by running the collector circuit pump at night in order to prevent stagnation from taking place the following day. It does not require additional components other than possibly a controller, relies on the often-used collector loop, requiring parasitic energy to do so but does not waste water. On the other hand, the method can only be used effectively when solar energy collection is not possible - unlike tank fluid purging which can be used preventively or during the collection period - and must necessarily anticipate periods of mismatched supply and demand, either using predictive or conservative controls [2,3].

The implicitly wasteful nature of both methods contrasts with their low implementation cost but can nevertheless penalise the performance of SDHW systems. At the same time, cooling the tank results in lower collector temperatures 
and higher PV yields for solar cells exhibiting negative cell efficiency temperature coefficients, although these are generally low in absolute value (e.g., $-0.45 \% / \mathrm{K}$ for monocrystalline silicon). In other words, these methods are likely to contribute to a degradation of the system's energy efficiency and cost-effectiveness, which is unlikely to be outweighed by the positive effect on the electrical performance of PV-T systems $[1,2,5]$. Nevertheless, this hypothesis needs to be tested in accordance with the scientific method and the magnitude of the performance variation quantified.

As such, the objective of the work described in this paper is to evaluate and compare implementations of tank fluid purging and night cooling with respect to the problem of stagnation and their impact on the performance of residential SDHW systems using glazed PV-T collectors. Although these methods have been to some extent discussed in the literature prior to this effort, the emphasis has not been on quantifying the effect they have on the performance of SDHW PV-T systems [7].

In order to do so, dynamic annual simulations were conducted. These focused on a reference system without any stagnation control method and systems employing each control method or both as a way to evaluate their potentially complementary nature and implications for systems with more frequent stagnation events such as space heating systems. Finally, the results were primarily analysed from the viewpoint of primary energy efficiency but other figures of merit were considered, namely overheating impact, pump cycling and likelihood of premature system failure.

\section{Relationship to Smart Systems}

The research efforts undertaken and described in this paper concern the study of two overheating prevention methods, namely tank fluid purging and night cooling, whose use can be enhanced by the features commonly associated with so-called "smart systems", namely sensing, (internet) connectivity, informed decision-making and actuation [8]. These features could render the preventive use of both methods more reliable and overall better performing than alternative control schemes. For instance, rather than cooling the tank according to a static temperature setpoint during a given time window at night, the control unit could hypothetically determine which flow rate to use if any, for how long and the timing of the operation dynamically.

Ideally, preventive use of both methods should consider dynamic weather forecasts, occupancy rates, electricity prices and other factors to select the most appropriate method (if more than one is available) and timing, which would require a combination of internet connectivity, sensors and control modules with predictive capabilities able to use such information in a timely manner. In practice, a predictive stagnation control scheme could be too complex and costly to implement relative to its potential benefits over simpler methods. Therefore, the current study focuses on the evaluation of simpler stagnation control solutions for SDHW PV-T systems yet consistent with the features associated with "smart systems".

Concretely, the use of occupancy rate information possibly provided by sensors, schedules or remote communication with the main unit to disable the backup heater and/or select different night cooling setpoints for normal load and load absence 
periods were evaluated since these are simple to implement and also have advantages from the standpoint of energy efficiency and user comfort when users are away.

\section{System Overview}

The solar heating systems under consideration for the purposes of this study are small active (i.e., forced-circulation) residential grid-connected SDHW systems featuring parallel-connected glazed PV-T collectors supplying the electricity generated to the local utility grid. These systems typically have a collector area in the range of 4-6 $\mathrm{m}^{2}$, tanks sized according to specific storage volumes of $40-70 \mathrm{~L} / \mathrm{m}^{2}$ of collector area and featuring internal heat exchangers of the immersed coil variety, which have a propensity for low thermal stratification [9-11]. Moreover, the systems are prepared to perform night cooling of the tank whereas purging tank fluid requires an actuator valve on the demand loop. The generic diagram for all three systems evaluated (no stagnation control, night cooling and purging) is given in Figure 1.

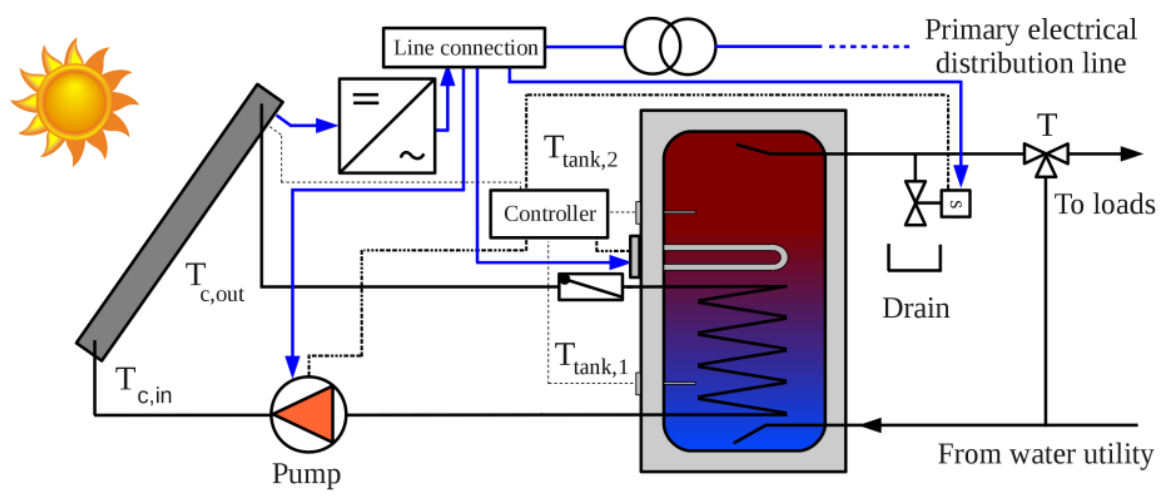

Fig. 1. Generic diagram for the solar domestic hot water (SDHW) systems studied.

Regular system operation is governed by simple controls, namely hysteretic controllers for the backup heater and pump as well as safety overrides designed to protect the system components other than the collector from high temperatures $\left(>95^{\circ} \mathrm{C}\right)$ by disabling heat carrier circulation. For the systems considered here, the backup heater is turned on once tank fluid temperatures drop below $55^{\circ} \mathrm{C}$ and remains on until temperatures reach $60^{\circ} \mathrm{C}\left(5^{\circ} \mathrm{C}\right.$ deadband $)$ and in doing so prevents the growth of legionella while not significantly enhancing the formation of limestone deposits $[10,12]$. Similarly, heat carrier circulation is initiated if the temperature difference $(\Delta \mathrm{T})$ between the heat carrier at the collector outlet and the tank fluid near the heat exchanger increases beyond the turn on setpoint $\left(\Delta \mathrm{T}_{\text {on }}=10 \mathrm{~K}\right)$ and ends if it drops below the turn off setpoint $\left(\Delta \mathrm{T}_{\text {off }}=2 \mathrm{~K}\right.$ ) leading to stagnation in the collector loop.

On the other hand, the night cooling takes place when three conditions are met. The first condition is a negative temperature difference between the collector and tank to indicate cooling is possible while the second and third conditions concern a timer 
enable (in this case, active between midnight and 5 a.m. local time) and a minimum tank temperature setpoint to regulate the cooling period and how much cooling is to take place, respectively. Moreover, the tank temperature setpoint alternates between a value for normal occupancy periods $\left(T_{n}\right)$ and another for periods of user absence $\left(T_{n l}\right)$, according to occupancy information conveyed by the "smart" system elements.

Conversely, tank fluid purging is triggered by any one of three conditions. The first condition is met when the collector fluid outlet temperature is within a preset tolerance $\left(\Delta \mathrm{T}_{\mathrm{f}, \mathrm{tol}}=5^{\circ} \mathrm{C}\right)$ of its maximum allowed level $\left(\mathrm{T}_{\mathrm{f} \text {,max }}=95^{\circ} \mathrm{C}\right)$ during fluid circulation. The second condition is met when the tank temperature exceeds the tank purge setpoint ( $\mathrm{T}_{\text {purge }}$, lower than the tank's maximum allowed temperature) and until the former drops to a safe level $\left(\mathrm{T}_{\text {safe }}\right.$, set to at least $5^{\circ} \mathrm{C}$ below $\left.\mathrm{T}_{\text {purge }}\right)$. The third and final condition is met when $\Delta \mathrm{T}$ approaches $\Delta \mathrm{T}_{\text {off }}$ during heat carrier circulation and the temperature difference between $T_{f, \max }$ and the tank fluid is lower than $\Delta T_{\text {on }}$. Although unlikely to be frequently triggered, it concerns high temperature cycling and could prevent the system from being stuck in high temperature stagnation since if stagnation were to set in once $\Delta \mathrm{T}$ dropped below $\Delta \mathrm{T}_{\text {off }}$ while $\mathrm{T}_{\mathrm{f} \text {,max }}-\mathrm{T}_{\text {tank }}<\Delta \mathrm{T}_{\text {on }}$, the collector fluid temperature could exceed the maximum value for which circulation is allowed $\left(95^{\circ} \mathrm{C}\right)$ before it could resume $\left(\Delta \mathrm{T}>\Delta \mathrm{T}_{\text {on }}\right)$ and after which fluid purging would not be effective since the system would be stuck until temperatures dropped.

\section{Methodology}

In order to address the proposed objectives, a set of annual dynamic simulations of the aforementioned SDHW PV-T systems were conducted. The choice of simulation work rather than physical experiments was based on the former's reasonable accuracy and the ability to compare systems under the same exact conditions in a time- and cost-effective manner. Annual simulation periods were selected due to the pertinence of evaluating the all-year round performance of the control methods and the system, even though stagnation events predominantly take place during Summer.

The simulations employed the models described in [2] except those for the stagnation controllers and the utility water temperature. The latter was modelled as $7^{\circ} \mathrm{C}$-amplitude $15^{\circ} \mathrm{C}$-average annual triangular wave, whose extrema were made to coincide (time-wise) with those of the outdoor temperature [12]. Typical meteorological year (TMY) data for Lisbon, Portugal $\left(38^{\circ} 42^{\prime} \mathrm{N}, 9^{\circ} 8^{\prime} \mathrm{W}\right)$ was used, as represented in Figure 2. However, the simulations assumed the lack of appreciable wind $\left(\mathrm{v}_{\text {wind }}=0 \mathrm{~m} / \mathrm{s}\right)$ as a worst case scenario and focused on common situations likely to lead to high stagnation temperatures in well-sized SDHW systems, namely the use of representative load patterns including Summer vacations and weekends off. A full load day corresponded to $200 \mathrm{~L}$ at $45^{\circ} \mathrm{C}$ and no load periods included a weekend off every four weeks and four one-week Summer vacations spread a month apart.

The simulations were run using MATLAB and most models implemented were validated against their respective counterparts from other well known simulation tools, namely TRNSYS, as described in [2]. Conversely, the dynamic PV-T collector model used is based on the equation for the quasi-dynamic test method featured in the standard EN 12975-2:2006 and reproduces the performance of the PV-T collector 
described in [1], which was measured according to the aforementioned standard. Moreover, the system's performance is in line with the results found in [13], which focused on the same location, using comparable PV-T technology and areas.

At the same time, the dynamic PV-T collector model used does not incorporate longwave radiative heat losses explicitly $\left(\mathrm{c}_{4}\right.$ or $\left.\varepsilon=0\right)$, which has thermodynamic implications particularly for night cooling with PV-T collectors lacking lowemissivity coatings, as is the case [1]. Nevertheless, the implications are arguably minor for the present study since the temperature differences between the hot storage tank and the outdoors still allow for significant convective heat transfer (and thus a conservative cooling power assessment) whereas night cooling of cold storage tanks (e.g., used in space cooling systems) requires radiative heat transfer [14]. Additional information on the parameters used, unless stated otherwise, can be found in [2].

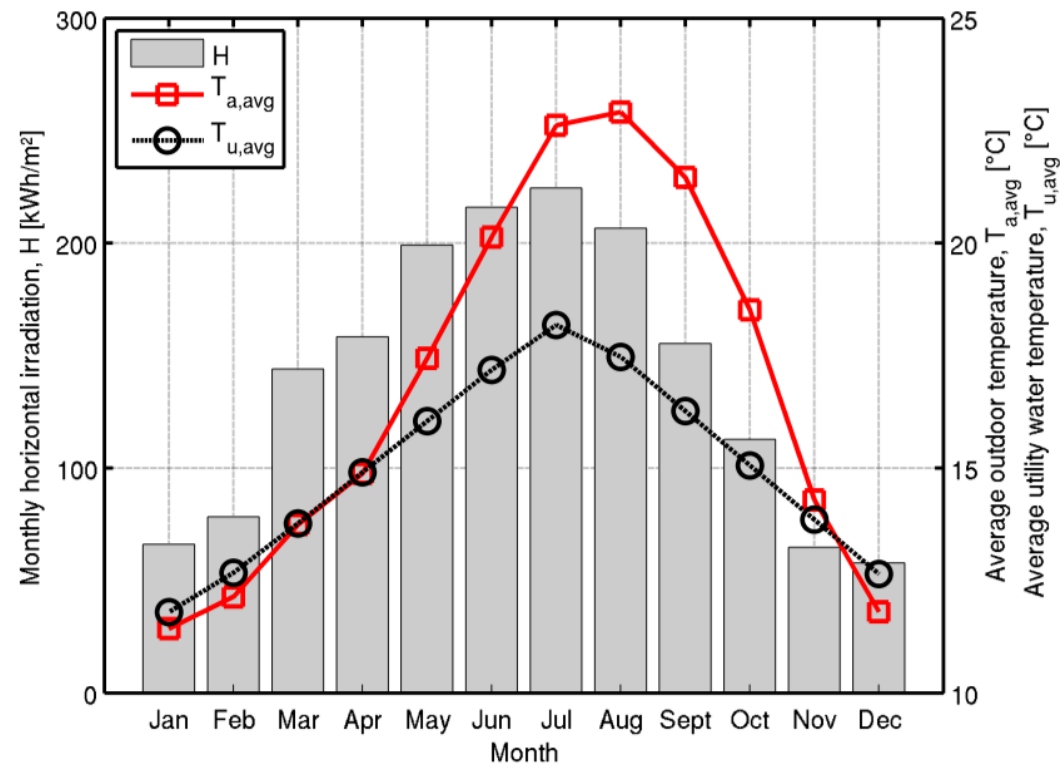

Fig. 2. Monthly horizontal irradiation $(\mathrm{H})$, average outdoor $(\mathrm{Ta}, \mathrm{avg})$ and utility water temperatures (Tu,avg) according to the (Lisbon) TMY data used in the simulations conducted.

The simulations' primary results were used to assess the system's primary energy efficiency using a weighted primary energy savings adapted from [15] and defined as:

$$
\mathrm{Q}_{\mathrm{pes}}=\mathrm{f}_{\mathrm{pv}} * \mathrm{E}_{\mathrm{pv}}-\mathrm{f}_{\mathrm{par}} * \mathrm{E}_{\mathrm{par}}-\mathrm{f}_{\text {aux }} *\left(\mathrm{E}_{\mathrm{aux}}-\mathrm{E}_{\mathrm{ref}}\right) \text {. }
$$

where the primary energy factors for PV electricity $\left(f_{\mathrm{pv}}\right)$, parasitic energy $\left(f_{\text {par }}\right)$ and auxiliary energy $\left(f_{\text {aux }}\right)$ were all set to 2.5 (general purpose electricity) [16]. Moreover, the backup heater (i.e., an immersed electrical heating element) efficiency to $100 \%$, the power converter efficiency to $95 \%$ and the pump power $\left(\mathrm{P}_{\text {pump }}\right)$ defined as a cubic function of the collector array mass flow rate $\left(\mathrm{m}_{\mathrm{c}}\right)$ according to (2), where the pump power coefficient $\left(\mathrm{K}_{\mathrm{p}}\right)$ was set to $1000 \mathrm{~W}^{1} \mathrm{Kg}^{-3} \mathrm{~s}^{3}$ after [17]. 


$$
\mathrm{P}_{\text {pump }}=\mathrm{K}_{\mathrm{p}} * \mathrm{~m}_{\mathrm{c}}{ }^{3} .
$$

\section{Simulations and Analysis}

The simulations revealed marginal primary energy savings and cumulative overheating period variations as the result of disabling the backup heater during periods of low energy demand. In particular, the increase in $\mathrm{Q}_{\text {pes }}$ from this measure was limited to no more than $2 \mathrm{kWh}$ for all flow rates whereas the reduction in cumulative overheating was only observed at low flow rates and limited to less than 3 hours. These results can be explained by the fact that the tank is usually charged during those periods and because overheating is more likely at low flow rates.

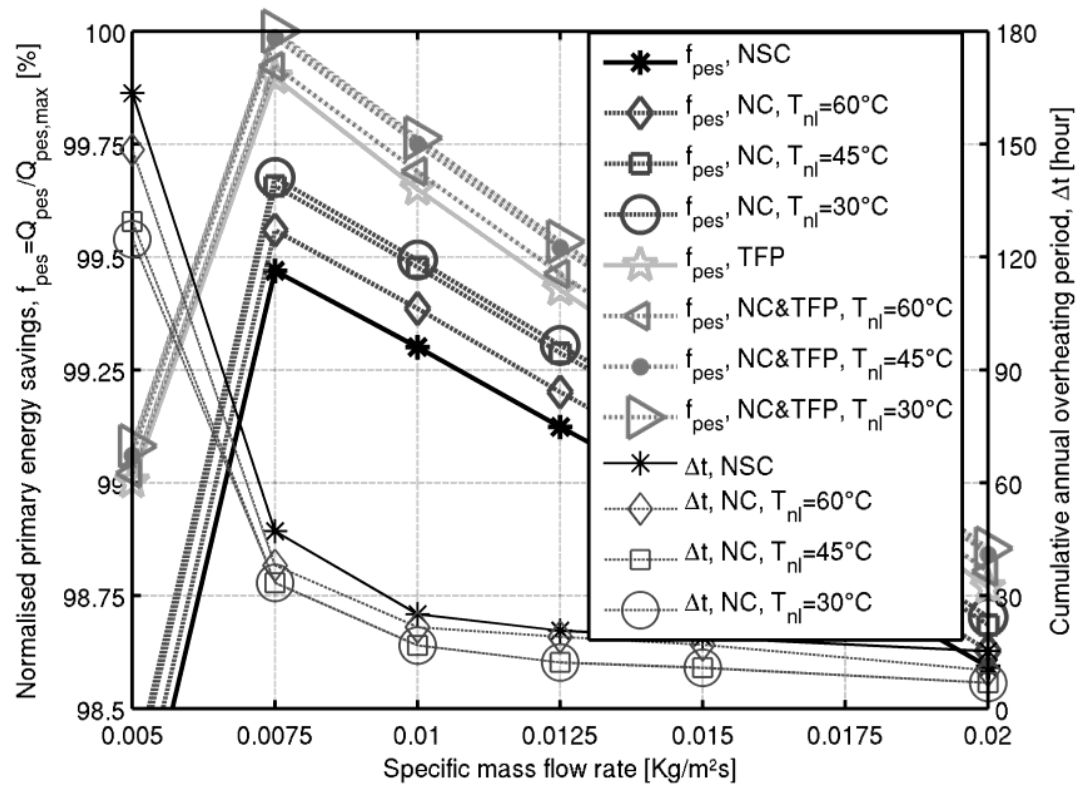

Fig. 3. Cumulative annual duration of overheating periods $(\Delta t)$ and normalised primary energy savings $\left(f_{p e s}\right)$ versus the specific mass flow rate $\left(m_{c} / A_{c}\right)$ for the SDHW PV-T systems simulated. Legend: NSC, no stagnation control; $\mathrm{NC}$, night cooling $\left(\mathrm{T}_{\mathrm{n}}=80^{\circ} \mathrm{C}\right.$; no load mode limited to vacations, i.e., excludes weekends); TFP, tank fluid purging $\left(\mathrm{T}_{\text {purge }}=85^{\circ} \mathrm{C} ; \mathrm{m}_{\text {purge }}=\mathrm{m}_{\mathrm{c}}\right)$.

With regard to stagnation control schemes, the simulations revealed night cooling as having a limited ability to prevent collector overheating, unlike tank fluid purging. Concretely, none of the systems simulated using tank fluid purging overheated - in contrast with results reported in [2] - while those relying exclusively on night cooling still overheated for at least a few hours annually although less than without a stagnation control method, as exemplified in Figure 3. The inadequacy of night cooling for overheating prevention did not result from low collector loop cooling power but rather the inability to predict the need for cooling as such, as overheating 
was observed even during full load days in addition to low demand periods - either vacations or weekends off. Moreover, meeting the night cooling tank temperature setpoint while employing the nominal mass flow rate used during the daytime was routinely achieved in a fraction of the time available to do so (the average night cooling cycle lasted under 3 hours but some lasted almost 5 hours, particularly at the lowest flow rates) and overheating tended to drop as either of the setpoints was lowered, although 'no load' setpoints lower than $45^{\circ} \mathrm{C}$ did not substantially reduce it.

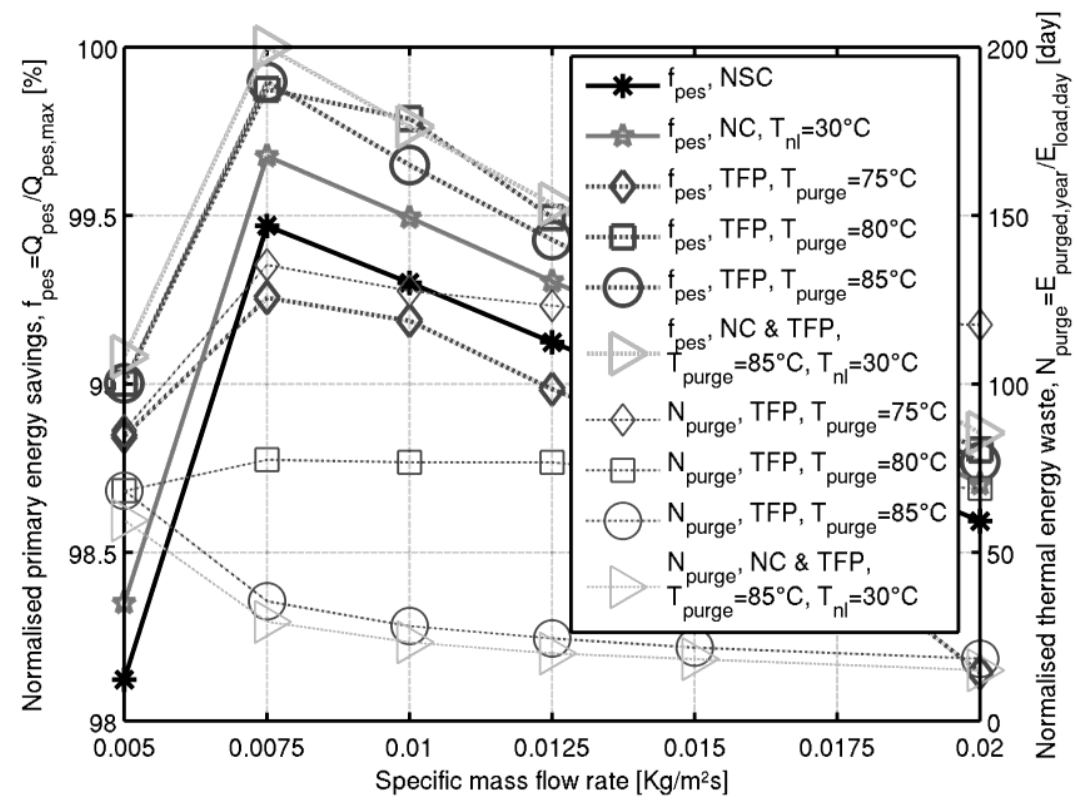

Fig. 4. Normalised primary energy savings ( $\left.f_{\text {pes }}\right)$ and normalised thermal energy waste due to fluid purging $\left(\mathrm{N}_{\text {purge}}\right.$ ) versus the specific mass flow rate for the SDHW PV-T systems simulated. Legend: NSC, no stagnation control; $\mathrm{NC}$, night cooling $\left(\mathrm{T}_{\mathrm{n}}=80^{\circ} \mathrm{C}\right.$; no load mode limited to vacations $)$; TFP, tank fluid purging $\left(\mathrm{T}_{\text {safe }}=\mathrm{T}_{\text {purge }}-5^{\circ} \mathrm{C} ; \mathrm{m}_{\text {purge }}=\mathrm{m}_{\mathrm{c}}\right)$.

At the same time, tank fluid purging either individually or combined with night cooling led to a substantial volume of water being flushed, mainly at low specific mass flow rates and predominantly during the Summer. While the water volume itself was not recorded, the energy wasted as the result of purging using tank purge setpoints from $75^{\circ} \mathrm{C}$ to $85^{\circ} \mathrm{C}$ ranged from 88 up to $927 \mathrm{kWh}$ for the lowest flow rates, which is equivalent to approximately 13 and 135 full load days. Alternatively, this corresponds to between 1.2 and $14.3 \mathrm{~m}^{3}$ of water at $\mathrm{T}_{\text {purge }}$ being replaced by utility water at Summertime temperatures $\left(18.5^{\circ} \mathrm{C}\right)$ - all reasonable estimates for the estimation of the actual volume of water purged - which is equivalent volume-wise to between 6 and 72 normal load days annually. However, the minimum energy waste and equivalent volume corresponding to the use of tank fluid purging as stand-alone were $126 \mathrm{kWh}$ (18 days) and $1.6 \mathrm{~m}^{3}$ (8 days), respectively. Thus, combining both methods allowed for a reduction of the amount of purging and energy waste (see Figure 4) and effectively constitutes a more environmentally viable solution. 
Primary energy efficiency-wise, PV-T systems using night cooling, tank fluid purging or both were able to outperform those not using any stagnation control method, particularly at low and medium collector specific mass flow rates, high purge setpoints $\left(80\right.$ and $\left.85^{\circ} \mathrm{C}\right)$ and if night cooling was limited to vacation periods, as shown in Figures 3 and 4. Conversely, excessive purging brought on through the use of purge setpoints as low as $75^{\circ} \mathrm{C}\left(\mathrm{T}_{\text {safe }}=70^{\circ} \mathrm{C}\right)$ inverted this trend while still reliably preventing overheating. Similarly, allowing night cooling during short 'no load' periods (i.e., weekends off) resulted in less overheating, mainly at low flow rates, but also slightly lower performances, predominantly at high flow rates. On the other hand, the range of performance variation itself was not significant: from $-16 \mathrm{kWh}$ up to 35 $\mathrm{kWh}$ relative to a maximum $\mathrm{Q}_{\text {pes }}$ of $3633 \mathrm{kWh}$. Nevertheless, the general outcome reflects higher PV yields (up to $22 \mathrm{kWh}$ ) due to cell cooling, despite increases in the parasitic (up to $1 \mathrm{kWh}$ ) and auxiliary (up to $55 \mathrm{kWh}$, and highest at high flow rates) energy consumptions, which ultimately stemmed from the methods' ability to cool the tank and the correlation between high irradiance periods and the need for cooling.

Moreover, the performance enhancement was highest for systems using tank fluid purging, either exclusively or combined with night cooling of the storage tank, which proved to be the most effective schemes in preventing overheating and in securing the highest primary energy efficiency. In this regard, the combined use of tank fluid purging and night cooling led to the highest observed primary energy efficiency.

\section{Conclusions}

Dynamic simulations of SDHW PV-T systems were conducted to evaluate implementations of tank fluid purging and night cooling of the storage tank as overheating prevention methods. While none of the methods evaluated can be useful in the event of black-outs, the results have shown tank fluid purging as a more effective method for overheating prevention than non-predictive night cooling of the storage tank. As such, the tank fluid purging implementation used for this study seemingly overcame the overheating problems reported in the literature.

Performance-wise, the PV-T systems simulated using tank fluid purging, night cooling or both combined surpassed the primary energy efficiency of the reference PV-T system not using any stagnation control method. In particular, the combined use of both individual methods led to the best performances of all, although the performance differences are arguably within the simulations' error range.

Moreover, combined use of both methods reduced the volume of water purged relative to the individual use of tank fluid purging, which proved significant. Thus, fluid purging is not environmentally sound vis-à-vis water scarcity, particularly if used in space heating systems, and can be completed inexpensively by night cooling.

With regard to the implementation tweaks conceivably possible using features associated with "smart systems", the simulations did not reveal noticeable energy efficiency increases by using occupancy information to disable the auxiliary system. Conversely, using that information to alternate between normal and (lower) 'no load' night cooling setpoints reduced the cumulative duration of overheating events annually - even if insufficient to effectively prevent overheating as a whole - and 
improved the systems' primary energy efficiency. As such, night cooling has potential to improve and become the standard, low cost, effective and environmentally friendly overheating protection method for SDHW PV-T systems and others.

Acknowledgments. The current study was made possible by a doctoral grant (reference SFRH/BD/76747/2011) issued by the Foundation for Science and Technology (FCT). The authors would like to thank the National Laboratory of Energy and Geology (LNEG) and the Faculty of Science and Technology, New University of Lisbon (FCT-UNL) for the institutional support.

\section{References}

1. Dupeyrat, P., Ménézo, C., Rommel, M., Henning, H. M. Efficient single glazed flat plate photovoltaic-thermal hybrid collector for domestic hot water system. Solar Energy, 85(7), 1457-1468 (2011).

2. Magalhães, P., Martins, J., Joyce, A. Comparative analysis of overheating prevention and stagnation handling measures for photovoltaic-thermal (PV-T) systems. Energy Procedia, 91, 346-355 (2016).

3. Frank, E., Mauthner, F., Fischer, S. Overheating prevention and stagnation handling in solar process heat applications - Tech. rep. A.1.2- IEA SHC Task 49 - Solar PACES Annex IV (2015).

4. Hillerns, F. The behaviour of heat transfer media in solar active thermal systems in view of the stagnation conditions. IEA-SHC Task 26 Industry Workshop. Borlänge, Sweden; April 3, 2001 .

5. Lämmle, M., Thoma, C., Hermann, M. A PVT collector concept with variable film insulation and low-emissivity coating. Energy Procedia, 91, $72-77$ (2016).

6. Lämmle, M., Kroyer, T., Fortuin, S., Wiese, M., Hermann, M. Development and modelling of highly-efficient PVT collectors with low-emissivity coatings. Solar Energy, 130, 161-173 (2016).

7. Harrison, S., Cruickshank, C.A. A review of strategies for the control of high temperature stagnation in solar collectors and systems. Energy Procedia 30 (2012), 793-804.

8. Akhras, G. Smart materials and smart systems for the future. Canadian Military Journal, 1, 25-31 (2000).

9. Eicker, U., Solar Technologies for Buildings, Wiley (2003).

10.Kaltschmitt, M., Streicher, W., Wiese, A., Renewable Energy: Technology, Economics and Environment, Springer (2007).

11.Cruickshank, C. A. \& Baldwin, C. Letcher, T. M. (Ed.) Storing Energy, With Special Reference to Renewable Energy Sources Sensible Thermal Energy Storage: Diurnal and Seasonal Elsevier, pp. 291-309 (2016).

12.Dupeyrat, P., Ménezo, C., Fortuin, S. Study of the thermal and electrical performances of PVT solar hot water system. Energy and Buildings, 68, 751-755 (2014).

13.Silva, R. M., Fernandes, J. L. M. Hybrid photovoltaic/thermal (PV/T) solar systems simulation with Simulink/Matlab. Solar Energy, 84, 1985-1996 (2010).

14.Eicker, U., Dalibard, A. Photovoltaic-thermal collectors for night radiative cooling of buildings. Solar Energy, 84, 1322-1335 (2011).

15.Lämmle, M., Fortuin, S., Hermann, M., Thermisches management von pvt-kollektoren ergebnisse aus systemsimulationen (2015).

16.DIN V 18599-1 Berichtigung 1, Ber 1:2013-05 (May 2013).

17.Nhut, L. M., Park, Y. C. A study on automatic optimal operation of a pump for solar domestic hot water system. Solar Energy, 98, 448-457 (2013). 